\title{
IMPLEMENTATION OF HUMAN RESOURCES INFORMATION SYSTEMS IN INDUSTRIAL REVOLUTION 4.0: CASE STUDY OF SEKOLAH TINGGI PARIWISATA BALI INTERNASIONAL
}

\author{
Kadek Ari Styawati ${ }^{1}$, A.A.N. Eddy Supriyadinata Gorda ${ }^{2}$ \\ Undiknas Graduate School ${ }^{1,2}$, Indonesia \\ arix190416@gmail.com ${ }^{1}$,eddy_supriyadinata@yahoo.com²
}

\begin{abstract}
The rapid development of information and communication technology offers solutions in effective and efficient organizational management. The implementation of information technology becomes an important aspect in the competition in the digital arena. This study aims to examine in depth about how the application of HRIS in STPBI. The research results showed that the implementation of HRIS at STPBI is used as a strategic activity in optimizing HR functions. The transformation and implementation of HRIS has several supporting and inhibiting factors. These supporting and inhibiting factors are combined in the development of HR in line with the theoretical and literary concepts used in this study. Through integrated work synergies in the field of staffing, transparency and availability of information is very helpful in decision making. The implementation of HRIS at STPBI is based on the paradigm of a balance between supporting factors and inhibiting factors.
\end{abstract}

Keywords: Human Resources Information Systems, information system implementation, strategic activity in optimizing Human Resources

\section{INTRODUCTION}

Human resources (HR) have a very important role in various development sectors. Within the company itself, HR plays a very important role, in addition to HR in the company resulting in a company having to budget a significant amount of funds to increase HR in various ways (Silvia, 2014). HR is a very valuable asset for the organization, so human resource management is one of the main pillars of the organization in supporting integrated patterns of strategy and policy determination. HR development is very much needed to increase productivity and joint performance for the progress of the company. The Industrial Revolution Era 4.0 forced companies to pay extra attention to their employees

To increase productivity, the development and management of human resources becomes very vital. HR development and management can be done by providing refreshments through education and training and building HR systems that are in accordance with Industrial Era 4.0. Majeed \& Ozyer (2016) asserted that HR management is an effort to regulate the relationship between employees and the 
company as part of the main foundation. Therefore, if the company does not implement a clear HR management, it can be predicted that the company's foundation will be shaken, so that the vision will not be achieved, because the driving machine does not move in rhythm, or instead there is a conflict that will result in various decisions, one of which is caused by, for example, placement of promotions that do not meet the qualifications. Moreover, good HR must be balanced with good HR management, thereby reducing employee turnover due to dissatisfaction with the results of management decisions.

According to Arwildayanto (2012), no matter how good the facilities and infrastructure are owned if it is not supported by qualified human resources, the tertiary institution will not develop optimally and even tends to be static and maintain the status quo. The BAN-PT Accreditation Standards (2008) also show that one aspect that measures the quality assessment of a tertiary institution is Human Resources. In the field of management, it is explained that one of the elements in an organization is human resources. Shiri (2012) concluded that through good HR management will contribute to improving organizational performance. The combination of human resource management with information technology produces human resource management solutions known as the Human Resource Information System (HRIS). HRIS implementation will result in an increase in the effectiveness of the human resource management function. All information is stored in one database and used together so it is very efficient. Kovach et al. (2002) state that HRIS is an example where business can be used not only to save administrative costs but also to generate strategic profits through the collection, processing and sharing of information.

The presence of a management system in HR management makes it easier for HR management because the whole procedure is carried out efficiently and is recorded automatically. Such systematic procedures include: collecting, storing, retrieving, and validating data by organizations about human resources, and personnel activities. The application of HRIS will not only ease the work of personnel, but also can create a work culture that supports and cooperates with each other. Thus, HRIS does not only have a good impact on reducing administrative processes such as recruitment, employee management, regulating employee rights and obligations, but also has an important role in creating a coordinating culture. It needs to be emphasized again, a coordinating culture, a healthy work culture is very much needed in maintaining company stability.

The HRIS not only has a good impact on reducing administrative processes such as hiring, managing employees, regulating employee rights and obligations, but also has an important role in creating a coordinating culture. HRIS will eliminate injustice or disparity in rights, because all forms of reward have been well calculated in the form of a system that automatically records and evaluates overall employee performance, therefore, all assessments can be done transparently, fairly and honestly.

In connection with the importance and efficient implementation of HRIS in HR management, which has also been mentioned previously has a good impact on company performance, many companies in Indonesia have begun to implement this system. Suharti \& Sulistyo (2018) said that since 2002 companies in Indonesia have 
started using HRIS for the management of human resources. So, for almost a decade more, many companies in Indonesia have begun to implement this system, given the effectiveness in form healthy employee performance. Of course, not only companies should pay attention to the implementation of HRIS, but universities also pay attention to this in order to produce quality graduates, one example is Sekolah Tinggi Pariwisata Bali Internasional (STPBI). This school has gain trust and praised from not only Balinese people but also people throughout the country (Lestari, 2015). Research conducted by Firmansyah and Nugraha (2018) states that the Human Resources System in a company is important for the smooth running of organizational tasks, the smooth running of administrative activities and the supporting elements of implementation. The results of this study were published in the Journal of Information Technology, Vol.1 No.1, May 2018.

Having various innovations carried out in order to support the quality of students' outcomes, STPBI is also improving itself internally, one of which is through improving HR management in the form of HRIS. The consideration to start using HRIS is the existence of several phenomena such as not being given appropriate training to employees. As a result, the performance is considered inadequate, and the person concerned is blamed.

STPBI increasingly strives for its employees to have a culture of good performance, and be able to efficiently choose employees who have credibility and quality who are qualified in policy-making positions. Therefore, STPBI began implementing HRIS. With this system, STPBI can use various personnel analysis, such as: job analysis, managerial decision organizing, and analyzing the situation of labor availability which includes recruitment or termination. This article aims to describe how the implementation of STPBI HRIS in the Industrial Revolution Era 4.0 , as well as the factors that hinder and support the implementation of management system in STPBI.

\section{METHODOLOGY}

The design of this study used qualitative methods. Qualitative methods were used to analyze research problems in more depth and focus on the implementation of human resource information systems. Data sources used were primary data sources namely documents of interviews and observations and documentation studies. The results of the interviews were analyzed with qualitative-descriptive analysis for the effectiveness of the implementation of HRIS and knowing the results of the application of HRIS. The research instrument used was the researcher himself or the human instrument as a filter and qualitative data collector. In addition, the research instrument in the form of an observation check list was used by researchers to collect other primary data. Data collection techniques used were the study of documentation for secondary data, interviews and observations for primary data. Determination of informants was done by using purposive sample techniques with subjective types. The number of informants was determined based on the consideration that the informants came from different fields and were involved and related to the research topic being studied. Verification of the validity of the results of the analysis was done by descriptive analysis, which was describing 
and comparing data both interview data, documentation studies and questionnaire results.

\section{RESULTS AND DISCUSSION}

Higher education institutions are required to be able to use information technology to be able to manage human resources more effectively and efficiently. Higher education institutions also have a field that deals with many matters relating to staffing, so in the 4.0 era it began to be known as the term human resource information system known as HRIS. In tertiary institutions, the utilization of the Human Resource Information System is expected to be able to improve business performance and competitiveness when the need for accurate information is fast and the availability of data for the decision-making process is needed. HR Information System as an information system needs to be designed in an integrated manner so that the efficiency of HR data management as a source of information can be maximized (cf. Mathis \& Jackson, 2006). HR data processing is expected to produce information and data in the form, structure, nature or contents that are more useful. The characteristics of the human resource information system are expected to be of quality by meeting one important indicator, namely the level of relevance where an information is truly useful for an action decision, the exact time in which the information comes when needed so it is useful for decision making, and the accuracy in which information is free from mistakes.

This is consistent with the interview data conducted with the head of STPBI as quoted in the data below:

"We really want to continue to develop the system so that it will be made easier for each decision making. The next development is, all aspects related to HR needs, for example starting with the employee entering the campus, then he was appointed as a probationary period, after that according to the terms of appointment as a permanent employee then when he should improve himself, when he should be given training, when he is if he wants to continue his education ... we must record it all well so that our expectations with a good record then we can provide good planning, then we can also provide good planning and service, then also we cannot provide something arbitrarily because the data already exists "

This is the main key of the implementation of SISDM at Sekolah Tinggi Pariwisata Bali Internasional. STPBI is highly demanded to conduct and develop good and correct data management of human resources. This is consistent with the theory put forward by Rivai (2009) related to healthy HR decisions, one of which is based on the availability of good and quality HR information. In the context of HR information management in the environment of Sekolah Tinggi Pariwisata Bali Internasional, the acquisition and search for quality information is needed to achieve company goals because information is a source of evaluation of the development of organizations, institutions, companies and departments.

Discussion related to the relevance and importance of HRIS implementation shows that with this information system can organize HR management and 
management in higher education to be able to support decision making by providing information through information technology media quickly, precisely, accurately, and integrated. Because, Human Resources (HR) become the dominant element in a service or production business. The discussion of the findings of this data is in line with the results of research conducted by Firmansyah and Nugraha (2018) which states that the Human Resources System in a company is important for the smooth running of organizational tasks, the smooth running of administrative activities and the supporting elements of implementation. The results of this study were published in the Journal of Information Technology, Vol.1 No.1, May 2018. In the context of HRIS implementation, they explained that the design and implementation and testing of this system can be used as a platform that supports the use of browsers and internet access so as to facilitate human staff capital in the distribution, collection and calculation of employee values is equipped with a dashboard that contains information so that information about human resources at the company can be obtained quickly.

From the analysis of interview data and compared with research conducted by Firmansyah and Nugraha (2018) it is known that HRIS can be implemented in a web-based human resource application program, universities also do not need to reinstall applications in every user when there are updates or changes and HRIS can designed on various platforms that can run a browser and connect to an internet connection and can be used as a medium for distribution and staff assessment forms. When confirmed related to this, in the interview session the Chairperson of STPBI said that the inhibiting factor for the implementation of HRIS in the STPBI environment was the HR factor itself as quoted in the interview below:

"The inhibiting factor is actually the HR who has long worked on campus, and he does not want to comply with the development of information even though we have actually given the opportunity but there are some who actually belong to the previous generation, it is very difficult for us to change their mindset with our contents with new technological knowledge, but however we must force employees to persevere, with that compulsion they will be able to learn "

The solution to the inhibiting factors of the implementation of HRIS is by requiring organizationally for every employee to participate in the development to be able to implement HRIS fully in STPBI. This inhibiting factor has theoretically been revealed by Rivai (2009) which illustrates the importance of the system and process of all activities in the staffing section starting from (1) recruitment; selection; placement; forecasting; HR planning; career planning and others, (2) maintenance through the provision of compensation; compensation; training benefits; safety and health; and employment relations, (3) Utilization through placement; management guidance; inventory skills; performance assessment; and performance standards, (4) Evaluation through personal research: economic analysis; HR analysis; assessment of potential; and HR audits. Thus, the dynamics of HR management at Sekolah Tinggi Pariwisata Bali Internasional requires more serious handling to reduce the inhibiting factors that could interfere with the implementation of HRIS as data presented by the head of STPBI. Existing human 
resources need to develop themselves with information technology systems that continue to develop.

The same thing was conveyed by other respondents, namely deputy chairman IV in the field of Cooperation and Foreign Relations. He stated that the implementation of HRIS needs to be further improved, because HRIS can play a role as data sharing between departments. HRIS will be very helpful in mapping lecturers and lecturers and can be used as a reference for decision making. Below is a breakdown of interview data outlined in this regard.

"I hope that there is data synchronization, data sharing from each department that can be accessed from those who need it without changing the original data, for example staffing under the district head and academic heads need to synchronize data, STPBI should have 1 reliable database that can really be used to make decisions when wanting to hold a lecturer recruitment, the point is the existence of data sharing that can be accessed in the loyal department.

This interview data excerpt indicates that the implementation of HRIS has not been carried out in harmony with the times that emphasize the management of human resources effectively and efficiently. With the development of a human resource management information system can help the organization of higher education. Management information systems are able to provide information about the real conditions of the organization so that they can support the improvement of the quality of an institution. Associated with the theory put forward by Scott (2001) which reveals that information systems are useful for carrying out certain specific tasks that are essential for the functioning of the organization. This shows that there is a positive correlation between theory and implementation of HRIS at STPBI so that it can be said that the era of the industrial revolution 4.0 requires a comprehensive HR management system.

Development and implementation of HR information systems need to be accompanied by goodwill management and ethics of all the organs underneath. Because, sometimes the problems that occur in organizations are strongly influenced by management and morals. This is often a challenge in the overall implementation of HRIS. In theory as revealed by Sutabri (2012) that the information system is a system within an organization that meets the needs of daily transaction processing, supports operations, is managerial with the strategic activities of an organization in order to be able to provide reports needed for outsiders. This theory emphasizes the mechanistic aspect. In this context, the implementation of HRIS needs to be able to be carried out in a more measurable manner and pay attention to ethics and ethics and be accepted by all parties. This was revealed in the interview data obtained by researchers as quoted data below:

"Of course he is based on the system and also how to instil ethics is also very important and good manners, that is the main and that is likely to be reduced in era 4.0 because all based on the system, resulting in interaction between fellow humans is reduced because of all access through the system. There are companies that work with negligee, shorts, invite dogs .. because 
he doesn't pay attention to it, the important thing is access to the system smoothly, so ... guest contact human to human is reduced. What is needed in this 4.0 era besides the ability to use and understand the system, but no less important is ... morals, ethics and manners ... because after all we will definitely interact "

Implementation of HRIS is important to pay attention to ethical and ethical aspects because the world of work in an organization cannot be avoided. Although, the theory put forward by O'Brien and Marakas (2014) states that information systems consist of human resources, hardware resources, software resources, data resources, and network resources. Information systems depend on human resources, hardware, software, data, and networks to carry out input, processing, output, storage and control activities that convert data sources into information products. This concept is no less in touch with the value of human taste in the implementation of HRIS. This can be a barrier to the total implementation of HRIS because of work interactions and structural hierarchy. Therefore, the role of socio-culture in the context of ethics and ethics in interacting needs to be integrated in HRIS.

System analysis can also be done by knowing the obstacles and inhibiting factors in the implementation of HRIS in tertiary institutions. This inhibiting factor needs to be balanced with the supporting factors that exist in STPBI. The supporting factors are the availability of adequate human resources, facilities and facilities that are adequate and the availability of funds to support the development and implementation of HRIS at STPBI. In addition, the increasingly dynamic STPBI growth at this time demands the ability to respond amid various changes. This growth has now begun to be offset by the use of information technology. The implementation of information technology in the STPBI environment can be seen in most existing departments. With the existence of various supporting factors, the implementation of HRIS at Sekolah Tinggi Pariwisata Bali Internasional is adequate.

The findings and discussion of this data are consistent with the theory put forward by Sidh (2013) which states that in today's dynamic global business environment, higher education institutions are required to be able to use information technology. Anatan and Ellitan in Suwatno (2009) also revealed that theoretically there are five important values that support organizations in making decisions, namely: (1) Information Technology, (2) Excellent Performance, (3) Better Opportunities, (4) Trust, (5) Without limitations. So, in practice, business organizations need information technology to obtain information as a basis for decision making (Suzanto \& Sidharta, 2015). The results of the interview as explained above show the concordance between theory and conditions in the field, mainly related to the importance of HRIS in the management of human resources in tertiary institutions.

In the field of organizational management, including tertiary organizations, it was explained that one of the elements in the organization was human resources. $\mathrm{HR}$ is an organizational resource that needs to be managed efficiently and effectively. Research conducted by Shiri (2012) concluded that through good HR management will contribute to improving organizational performance. The amount 
of information that must be managed related to human resources raises the problem of a high level of complexity.

This also happened in the implementation of HRIS at Sekolah Tinggi Pariwisata Bali Internasional as the above respondents' data expression, so that the complexity of the problems in the HR field would be difficult to solve with a manual HR information system. For this reason, theoretically and empirical facts obtained from interview data in the field, complex problems in managing information related to HR can be overcome by the construction of computer-based HR information systems. The combination of information technology and HR management will provide the best solution for HR management in tertiary institutions. The implementation of HRIS will result in an increase in the effectiveness of the human resource management function and quality assurance of all activities of the academic community will be well managed. The findings of this empirical data and by comparison with the theory used, this shows that this research supports the results of previous research conducted by Shiri (2012) which shows that the use of HRIS in an organization provides work results that are more effective and faster, and bring improvements to the function human resources as a whole, have even helped in aligning human resource practices with organizational strategies to improve the efficiency of the HR function.

In the context of work within the STPBI environment, the effectiveness and efficiency of HR performance is also felt by students who are the main customers of STPBI operations. This was revealed from the interview data conducted with two students from different study programs. They revealed that the implementation of HRIS can improve services to students and can be used as a reference for future service improvements, including services provided by lecturers. Excerpts of interview with Lynette Antonia, a student of diploma IV Hospitality Management, related to services to students related to the implementation of HRIS at STPBI.

"The services provided by STPBI are already maximum. Maybe the information needs to be improved. So, in some situations that information we get from several parties and different. Sometimes if it's also confused, maybe it's also a mistake from students asking not real people. In general, the service is good maybe yes. Like yesterday there was a new system of Impa Print, straight from the SIAKAD. "

The results of this interview illustrate that the implementation of HRIS at Sekolah Tinggi Pariwisata Bali Internasional can also indirectly support academic services to students. Services to students will be closely related to the quality of graduates. To be able to produce quality graduates, STPBI is required to be able to manage its resources, including students, human resources, and facilities and infrastructure. According to McLeod (Suwatno, 2009, p.331) information is data that has been processed or data that has meaning. Furthermore, according to Rivai (2009) information is a critical link to the success of various possibilities for planning. The quotation and discussion of interview data above conducted with students related to academic and non-academic services shows the validity and reliability of the theory related to the importance of data processing in providing services in higher education as theoretically raised by Mc. Leod and Rivai. 
Processing data to be able to produce information is an activity of the mind with the help of hands or a piece of equipment that follows a series of steps in the formulation or a certain pattern to change the data, so that the data either in the form, arrangement, nature or contents become more useful. Only companies that can use their information effectively can benefit more effectively and more efficiently than their competitors (cf. Susanto, 2004). One of the most important and plays a role in the management of higher education is HR. Arwildayanto's research (2012) shows that no matter how good the facilities and infrastructure are owned if it is not supported by qualified human resources, the tertiary institution will not develop optimally and even tends to be static and maintain the status quo. In addition, the BAN-PT Accreditation Standards as a reference for quality in tertiary institutions also show that one aspect that is a benchmark for assessing the quality of a tertiary institution is Human Resources.

It is not possible to implement HRIS as a whole at STPBI, because there are other inhibiting factors that need to find alternative solutions. For example, financing factors for further development and maintenance and work habits inhibiting factors or can be called a work culture that is directly related to the implementation of HRIS. One example is related to the HR management transition from previous officials. The results of this interview data indicate that there are still a few obstacles in implementing HRIS in the STPBI environment. This has not yet led to the theory implemented by Mamun \& Islam (2016) which explains that the human resource information system is seen as a tool to create and disseminate information relating to human resources, which is aligned with the strategic direction of a company. Research conducted by Shiri (2012) found that the use of HRIS in an organization provides results that are more effective and faster, as well as bringing improvements to the overall function of human resources, even helping to align human resource practices with organizational strategies, thereby increasing efficiency of HR functions.

As a result of research conducted by Hendriks and Stratman (2007) which states that investment in IT is a large investment and in managing information technology. HRIS is a concept that has a focal point on the utilization of information technology development and characteristics as a manager of functions and applications. This is where financing appears in providing devices. Although, in the long run will be able to reduce tasks in the personnel department and can also reduce funding. Regarding operational financing in the management of information technology-based human resources, the previous researchers showed a positive trend that the implementation of HRIS can reduce funding as the results of research conducted by Blocher et al. (2002), Beadless (2005) and Pandya (2013) who say the same view that implementing HRIS in creating budget efficiency and providing cost savings that allows HR managers to turn their attention to provide better data analysis.

HRIS makes HR functions more efficient and provides better information for decision making. HRIS not only aims to help produce the right decisions in the field of human resources but also makes work related to human resources more efficient. The results of interview data obtained from the Head of Infrastructure 
Headquarters show that the implementation of HRIS is still around $50 \%$ and still needs to be improved. The following excerpt interview data regarding these:

"STPBI has implemented SISDM, but it has not been maximized, it needs to be improved and disseminated so that employees better understand what SISDM is and have been running $50 \%$ and need to be improved. The meaning of SISDM is a system that supports decision making by providing various necessary information, the information referred to here in the form of recruitment, education, training and placing employees in the right position.

The findings of this data are consistent with what the previous researchers said that a good system testing procedure is important to ensure the new system can operate as desired. According Jogiyanto (2005: 35) system development can be interpreted to compile a new system to replace the old system both overall and only improve the existing system. Thus, the development of HRIS has shown the role of HR in higher education to increase and become strategic. HRIS can provide more valid information and timely information. In addition, HR services have become easier as demonstrated by the implementation of HRIS at STPBI.

Vikas (2012) states "Human resource information system (HRIS) is an integrated system designed to provide information used in HR decision making. This means that the human resource information system is an integrated system designed to provide information used in HR decision making. Referring to the theory raised by Vikas above, the implementation of HRIS in STPBI has become an integrated system and plays a very important role now and the human resource information system and HRIS implementation is appropriate to carry out this role. For this reason, a proper implementation of HRIS is needed in accordance with the provisions set out in the STPBI work environment. Implementation of Information Systems Human resources at STPBI have collected data on each employee, recorded changes that occur, and store them in one data set (called a database). The database can be used as a source of data in the implementation of personnel administration and outputs that can be used as information to help policy making about human resources and in decision-making.

The implementation of the Human Resource Information System or HRIS at STPBI has provided various benefits in relation to HR management. This HRIS is very useful because the role of information technology is very helpful in maintaining mutual trust between employees and management. Another thing that has a positive value to the implementation of HRIS is the development of organizational culture and employee placement which will all be able to influence the success of higher education management. This is in line with the findings of previous studies, which are related to the ability to implement HRIS to be able to streamline the workforce, and be able to save time and also be able to improve competitiveness (cf. Batool, 2012). Battol further revealed that a well-implemented human resource information system would be able to give a role to career development. The implementation of human resource information systems makes it possible to develop employees in the organization, although it is sometimes said that HRIS also raises several problems for an organization such as fading the value of work sense in an institutional environment. 
A well-implemented human resource information system can also improve employee discipline as said by Khera (2012) that HRIS also helps in tracking employee attendance at work, knowing the regularities that apply and employee service to the organization. This shows the relationship of how HRIS assigns its role to work discipline.

The theory and literature review from previous research results used in the discussion of this study illustrates that the Human Resource Information System is a key management tool in collecting, maintaining, analyzing and reporting information, where the data collected, maintained and analyzed data are data about human resources or workers in a particular organization and HRIS also functions to convert data to conclusion information that is more accurate and can be used as a reference for decision making (Shaikh, 2012). Information system is a set of system forming components that have a link between one component and other components that aim to produce information in a particular field. It is known that there are three basic concepts in implementing HRIS at STPBI, namely gathering, processing and disseminating information. The information is collected from the environment inside or outside and allows distribution into or out of STPBI in accordance with applicable regulations. When compared with some of the concepts and results of previous studies, the discussion in this study has a common thread with the theoretical concepts expressed by previous studies, including Vikas (2012) stating "Human resource information system (HRIS) is an integrated system designed to provide information used in HR decision making. This means that the human resource information system is an integrated system designed to provide information used in HR decision making; Mathis (2006), "Human resource information systems are integration systems designed to provide information needed to make human resource decisions. The statement also showed that the human resource information system was designed to support various things in human resource activities that would be related or useful in making decisions in the field of human resource management.

The implementation of HRIS at STPBI is a system that integrates all relevant data, integrating relevant data is certainly very much needed by the organization so that the information system has benefits for HR management. In addition, integrating employee classes with compensation or salaries to be received by employees can also be done more accurately. The effectiveness and efficiency of the existing HRIS in the staffing section are used to understand HR policy patterns, actions and employee behavior and to identify gaps in the HR system and HR system effectiveness. This shows that the effective implementation of the Human Resources Information System at STPBI will have a broad reach or can be used in the management of tertiary institutions or it can also be used in other organizations. Human resource information systems perform various activities related to human resources in an organization which are expected to provide benefits for each human resource and also for leaders in deciding various policies related to human resources or employees in the organization. This HRIS is implemented integrally. An integrative information system is a system where all organizational units have a single information framework for the collection and use of information needed. Human resources play an important role as well as a key holder of organizational success in achieving planned organizational goals, so that 
the progress of an organization will greatly depend on how far the quality of human resources at STPBI.

\section{CONCLUSION}

The HRIS-based HR management paradigm in an institutional context cannot be separated from the support of management and the application users themselves. Through integrated work synergies in the field of staffing, transparency and availability of information is very helpful in decision making. The implementation of HRIS at STPBI is based on the paradigm of a balance between supporting factors and inhibiting factors. Because, the development of HRIS at STPBI is all activities carried out by all management and staff in facilitating the entire academic community to have the knowledge, expertise and or attitudes needed in handling work in accordance with their respective fields. Then, it can be concluded that the implementation of human resource information systems is very beneficial to career development and information transparency internally and externally.

From these conclusions it can be suggested for STPBI to continue to develop information systems, including developing them into web-based employee recruitment information systems to make it easier in terms of file selection as well as more effective and efficient. The implementation of HRIS will be better if the overall operation of both management and maintenance is carried out by the institution's IT team so that it is easier to manage and maintain the system. In addition, STPBI can provide periodic training to system users who will later play a role in the development and maintenance according to the conditions. With the study of the significance of the effect of supporting factors and inhibiting factors in the implementation of HRIS in tertiary institutions, this cannot be used as a guideline for further researchers to examine this theme in more detail. This research was also carried out at tertiary institutions which have just implemented HRIS so that this can also be taken into consideration for researchers who are interested in information systems and human resource management.

\section{REFERENCES}

Arwildayanto. 2012. Manajemen Sumber Daya Manusia Perguruan Tinggi Pendekatan. Jakarta: Ideas Publishing

Batool. 2012. Benefits and Barriers of Human Resource Information System In Accounts Office \&Azad Jammu \&Kashmir Community Development Program. International Journal of Humanities and Social Science Vol. 2 No. 3

Beadles, N., Lowery, C. M., \& Johns, K. 2005. The Impact of Human Resource Information Systems: An Exploratory Study in the Public Sector. Communications of the IIMA 39, 5 (4).

Beadles, Nicholas Aston, et al. 2005. "The Impact of Human Resource Information Systems: An Exploratory Study in the Public Sector" Communications of the IIMA, 5(4): 39-46. Diunduh dari: : http://scholarworks.lib.csusb.edu/ciima/ vol5/iss4/6, accessed on 25 August 2019 
Blocher, J. Edward, Kung H. Chen, Thomas W. Lin, 2002. Manajemen biaya.

Firmansyah, D dan Nugraha, R. 2018. Pengembangan Sistem Informasi Sumber Daya Manusia Berbasis Web. Bandung: Jurnal Eknologi Informasi, Vol.1 No.1, May 2018

Jogiyanto. 2005. Analisis \& Desain Sistem Informasi : Pendekatan Terstruktur Teori dan Praktek Aplikasi Bisnis.Yogyakarta: ANDI.

Khera, S.N. and Gulati, K., 2012. Human resource information system and its impact on human resource planning: A perceptual analysis of information technology companies. Journal of Business and Management, 3(6), pp.613.

Kovach, Kenneth A. 2002. Administrative and Strategic Advantages of HRIS. Employment Relations Today Journal. Volume 29, Issue 2. Accessed on May

2016 dari https:/www1.villanova.edu/content/dam/villanova/VSB/assets/ maggittiresearch/Human\%20Resource\%20Information\%20Systems\%20A dministrative $\% 20$ and $\% 20$ Strategic $\% 20$ Advantages.pdf

Lestari, Denok. 2015. Developing Communicative Competence of the Students at the Bali Hotel School by Implementing Instructional Role Play. Journal of Business on Hospitality and Tourism. 1(1). http://jbhost.org/jbhost/index.php/jbhost/article/view/31

Majeed, ZA \& ST Ozyer. 2016. "Implementation of the Human Resources Information Systems and Comparative Study of Various Platforms", Universal Journal of Engineering Science, 4(4): 66-78. DOI: 10.13189/ujes.2016.040402

Mamun \& Islam. 2016. Perception of Management on Outcomes of Human Resource Information System (HRIS). International Journal of Business and Social Research. Vol. 6 No. 2. Accessed on May 2016 dari http://www.thejournalofbusiness.org/index.php/site/article/view/837.

Mathis Robert L. dan Jackson John H. 2006, Human Resource Management, alih bahasa. Salemba Empat. Jakarta

O’Brien, J.A., \& Marakas, G. M.2014. Sistem Informasi Manajemen. Edisi 9. Buku 1. Jakarta: Salemba Empat.

Pandya, K. 2013. Network Structure or Topology. IJARCSMS, pp. 22-27.

Rivai, Veithzal, 2009. Manajemen Sumber Daya Manusia Untuk Perusahaan. Jakarta : Raja Grafindo Persada

Scott, G.M. 2001. Prinsip-Prinsip Sistem Informasi Manajemen. Jakarta: Raja Grafindo Persada, Jakarta, 2001

Shaikh, M.S. 2012. Human Resource Information System (HRIS) Designing Needs For Business Application. ZENITH International Journal of Business Economics \& Management Research Vol.2 Issue 1

Shiri, Shammy. 2012. Effectiveness of Human Resource Information System on HR Functions of the Organization: A Cross Sectional Study. Accessed on May 2016 dari http://www.davidpublishing.com/davidpublishing/upfile/11/14/ 2012/2012111401088443.pdf.

Sidh, R. 2013. Peranan Brainware Dalam Sistem Informasi Manajemen. Jurnal Computech \& Bisnis, 7(1), 19-29. 
Sidharta, I., \& Wati, M. 2015. Perancangan Dan Implementasi Sistem Informasi Urunan Desa(URDES) Berdasarkan Pada Pajak Bumi Dan Bangunan. Jurnal Computech \& Bisnis, 9(2), 95-107

Silvia, M. 2014. Pengaruh Motivasi, Disiplin Kerja Dan Lingkungan Kerja Terhadap Kinerja Karyawan PT. Inti General Yaja Steel. Jurnal Manajemen Sumber Daya Manusia. Semarang: Universitas Dian Nuswantor.

Suharti, L \& PR Sulistyo. 2018. "The implementation of human resources information system and it's benefit for organizations," Diponegoro International Journal of Business 1(1): pp. 1-7. Diunduh dari: http://ejournal2.undip.ac.id/index.php/ijb/index, accessed on 25 August 2019

Susanto, H.M., Mantja, W., Bafadal, I. dan Sonhandji, A. 2015. Pengembangan Sistem Informasi Manajemen Pendidik dan Tenaga Kependidikan. Malang: Universitas Negeri Malang. Jurnal Pendidikan Humaniora. Vol. 3 No. 2, Hal 93-105, June 2015

Sutabri, Tata. 2012. Analisis Sistem Informasi. Yogyakarta: Penerbit ANDI.

Suwatno. 2009. Manajemen Sumber Daya Manusia Teori Aplikasi Dan Isu Penelitian (Cetakan kedua). Bandung : Alfabeta.

Suzanto dan Sidharta. 2015. Pengaruh Kepuasan Transaksi Online Shopping dan Kepercayaan Konsumen Terhadap Sikap Serta Perilaku Konsumen Pada Ecommerce. Jurnal Computech \& Bisnis. Vol. 9 No.1

Vikas, K. 2012. Human Resource Information System: An overview. Anusandhanika / Vol. IV / No. II /pp. 80-83 